\title{
Myriad and the mass media: the covering of a gene patent controversy
}

\author{
Timothy Caulfield, LLB, LLM ${ }^{1,2}$, Tania Bubela, PhD, $L L B^{3}$, and C. J. Murdoch, BA (Hons) ${ }^{1}$
}

\begin{abstract}
Purpose: We explore how the print media in four jurisdictions framed the controversy surrounding Myriad Genetic's BRCA patents and consider the possible influence of media on public perceptions and policy reform. Method: We used a broad search strategy to collect newspaper articles from Factiva and Lexis/Nexis on Myriad Genetics and the $B R C A$ gene and identified the main triggers for those articles. We then selected articles on the BRCA gene patents for coding. The coding frame queried the presence or absence of either positive or negative statements about gene patenting and a subjective assessment of the tone of the article. We compared the differences in tone and number of positive and negative statements between jurisdictions (Australia, Canada, United Kingdom, and United States). Results: Myriad Genetic's BRCA1/2 gene patents sparked significant international newspaper coverage in comparison to other stories on gene patenting controversies. Only 55.9\% of 143 articles presented a variety of perspectives. The majority of articles (77.6\%) had a negative overall tenor; only $6.29 \%$ had a positive overall tenor, whereas $16.1 \%$ were neutral. There were significant differences in the overall tenor between jurisdictions, with Canadian coverage being overwhelmingly negative in comparison with the other three jurisdictions. The main triggers for news coverage were largely local licensing deals, actions at regional patent offices, and statements and publications by prominent figures. Conclusion: Myriad's patents were largely portrayed as a negative story, except in Utah where Myriad Genetics is located, and as an example of the problems associated with gene patents. The story was primarily framed as a social dilemma that needed to be addressed. In Canada there was a disproportionate level of coverage of the political response to the threat of patent infringement action against government testing laboratories and potential impacts on public health care. In Europe and elsewhere in the United States, the opposition to gene patenting at the European Patent Office predominated. In these contexts, our data provide some support that the media coverage helped to drive the policy agenda, although the resultant policy response received almost no media attention. Genet Med 2007:9(12):850-855.
\end{abstract}

Key Words: BRCA, breast cancer, commercialization, gene patents, media, Myriad Genetics, newspaper

Six years ago, a small Utah-based company sought to enforce its gene patent on a widely available predisposition test and, in doing so, triggered calls for national and international patent policy reform. ${ }^{1}$ Although challenged in some jurisdictions, ${ }^{2}$ Myriad Genetics holds the patents on the BRCA1/2 genes. In the summer of 2001, Myriad sent letters to agencies throughout the world stating all tests for the mutation, the

\footnotetext{
From the ${ }^{1}$ Health Law Institute, the ${ }^{2}$ Faculty of Law and School of Public Health, and the ${ }^{3}$ School of Business, University of Alberta, Edmonton, Alberta, Canada.

Timothy Caulfield, Health Law Institute, Law Centre, University of Alberta, 89 Avenue, 111 Street, Edmonton AB T6G 2H5, Canada. E-mail: tcaulfld@law.ualberta.ca

Disclosure: The authors declare no conflict of interest.

Supplementary appendixes are available via the ArticlePlus feature at www.geneticsinmedicine. org. Please go to the December issue and click on the ArticlePlus link posted with the article in the Table of Contents to view this material.

Submitted for publication July 17, 2007.

Accepted for publication August 23, 2007.

DOI: 10.1097/GIM.0b013e31815bf965
}

presence of which significantly increases the risk of breast and ovarian cancer, must be done through the Myriad laboratory or a Myriad licensee. ${ }^{3}$

This action was largely condemned by researchers, clinicians, and government agencies. ${ }^{2,4}$ In the policy documents that followed, the Myriad story was used as cautionary example of the issues associated with gene patents. An analysis of the policy reports published post 2002 shows that the Myriad story was, by far, the most referred to gene patent controversy. Indeed, the Myriad story was often used as a specific justification for patent reform. ${ }^{1}$

In this article we explore how the print media covered the controversies associated with the BRCA gene patents, particularly as they relate to Myriad Genetics. The popular media plays an important role in providing the public with information about science and biotechnology. ${ }^{5}$ The media also plays an important role in framing controversies and public perceptions about the risks and benefits of biotechnology. ${ }^{6,7}$ Given that gene patenting has long been and remains a controversial, albeit well established, practice, an exploration of how the me- 
dia covered this controversy may inform both the shaping of public perceptions and the motivation for policy reform. ${ }^{8}$

\section{METHODS}

We searched Factiva using the search string 'Myriad and

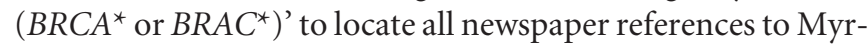
iad Genetics in Canada, Australia, the United Kingdom (UK), and the United States of America (US). We augmented newspaper articles by searching Canadian Newsstand for Canadian articles and using regional databases within Lexis/Nexis for each of Australia, UK, and US using the search string 'Myriad and "breast cancer" and patent.' We then manually inspected each article, retaining only those that referred specifically to Myriad Genetic's patents. This meant excluding conference minutes, stock exchange reports, trade magazines, and articles that mentioned the BRCA genes, but did not discuss the patents. For each year, we determined the main theme or event that triggered the media coverage (Appendix 1; available online only).

We developed a coding frame (Appendix 2; available online only) to test for the presence or absence of positional statements, either positive or negative, about gene patenting. These statements were generated from the literature and policy documents reviewed in Caulfield et al. ${ }^{1}$ The completeness of the coding frame was confirmed by the absence of entries in the "other" category for each type of statement. We considered overarching policy considerations, substantive patent law and process, and ethical concerns. The coding frame also captured the stakeholders who were cited in opposition and in defense of gene patents. On the whole, each type of statement and commentator appeared only once per article, so it was possible to tally the "Yes" categories to approximate a count of the number of times positive versus negative statements were made or commentators cited. Finally, the coding frame queried the overall tenor and balance of the article in relation to gene patenting and whether the article made any recommendations.

Two coders were trained to complete the coding frame. The two coders coded $10 \%$ of the articles together and discussed the interpretation of the coding frame to ensure intercoder reliability. To assess intercoder reliability, each coder independently scored the same random selection of 75 articles ( $52 \%$ of the total). We calculated intercoder reliability using Cohen's $\kappa$ for 54 of the coding questions. In all cases, the $\kappa$-statistic ranged from 0.685 to 1.000 , indicating good to excellent intercoder reliability; the $\kappa$-score was $>0.900$ for $63 \%$ of the coding questions. Most importantly, the $\kappa$-scores for the subjective measures of tenor, controversy, and balance were 1.000, 0.793 and 0.945 , respectively.

The possible categories for overall tenor of the article were negative, neutral, and positive. We compared tone between jurisdictions using a $\chi^{2}$ test, but combined the positive and neutral categories so that only one cell had an expected frequency below 5. ${ }^{9}$ We also compared the total number of positive and negative statements and the total number of positive and negative commentators between jurisdictions using Kruskal-Wallis tests. We used SPSS 13.0 for all statistical analyses.

In addition, to gauge the impact of the BRCA1/2 gene patent story relative to other disease gene patents, we searched Factiva newspaper databases for Australia/New Zealand, Canada, US, UK with no date restrictions for "'disease name' and gene and patent." We selected the disease genes based on coverage in international policy reports on gene patenting surveyed in Caulfield et al., ${ }^{1}$ and the gene patents listed in Cho et al. ${ }^{10}$

\section{RESULTS}

Myriad Genetic's BRCA1/2 gene patents sparked not only a strong response among policy makers, but also significant international media coverage in comparison to other potential stories on gene patenting controversies (Fig. 1). Initially, the media covered the sequencing in 1994 of BRCA1 by Myriad, the University of Utah, and National Institutes of Health researchers and the filing of the BRCA1 patent in the US. Interestingly, in the US, this story was framed as a dispute between Myriad and publicly funded National Institutes of Health researchers who had been left off the patent as inventors. The negativity of the coverage continued in the UK and US with the involvement of non-governmental organizations and a coalition of breast cancer activists who lobbied the European Parliament to oppose Myriad's patents. The story continued in 1997 in the UK with the controversy over the discovery of BRCA2 and the defensive patent filed by the public sector charity, Cancer Research UK. In 2000, Myriad's genetic tests and patents were used to exemplify the antithesis of President Clinton and Prime Minister Blair's statements about results of the Human Genome Project as the "common heritage of mankind."

Coverage in Australia was almost exclusively in the context of Myriad Genetic's licensing deal with an Australian company, Genetic Technologies, to provide BRCA testing in that country. The UK and Canada also covered licensing deals with local companies, Rosgen and MDS, respectively. The latter was originally a positive story whereby the licensing deal aimed "to provide greater access to Canadians." However, the tone changed in 2001 when Myriad sent cease-and-desist letters to Ontario Government laboratories to stop BRCA testing. This triggered an overwhelming negative political and media response, but received scant coverage elsewhere. In other jurisdictions, including the US, the predominant story was the opposition proceedings at the European Patent Office lead by the French Institut Curie. At the same time, in the US, Myriad received favorable coverage for its assistance in identifying victims of the World Trade Center bombings.

In Canada, coverage of Myriad's disputes with the provinces continued through 2003 as most provinces refused to comply with Myriad's threats of patent infringement and then coverage ended abruptly. In other jurisdictions, media continued to cover the controversies at the European patent office: the revocation of Myriad's first BRCA1 patent and the granting of a 


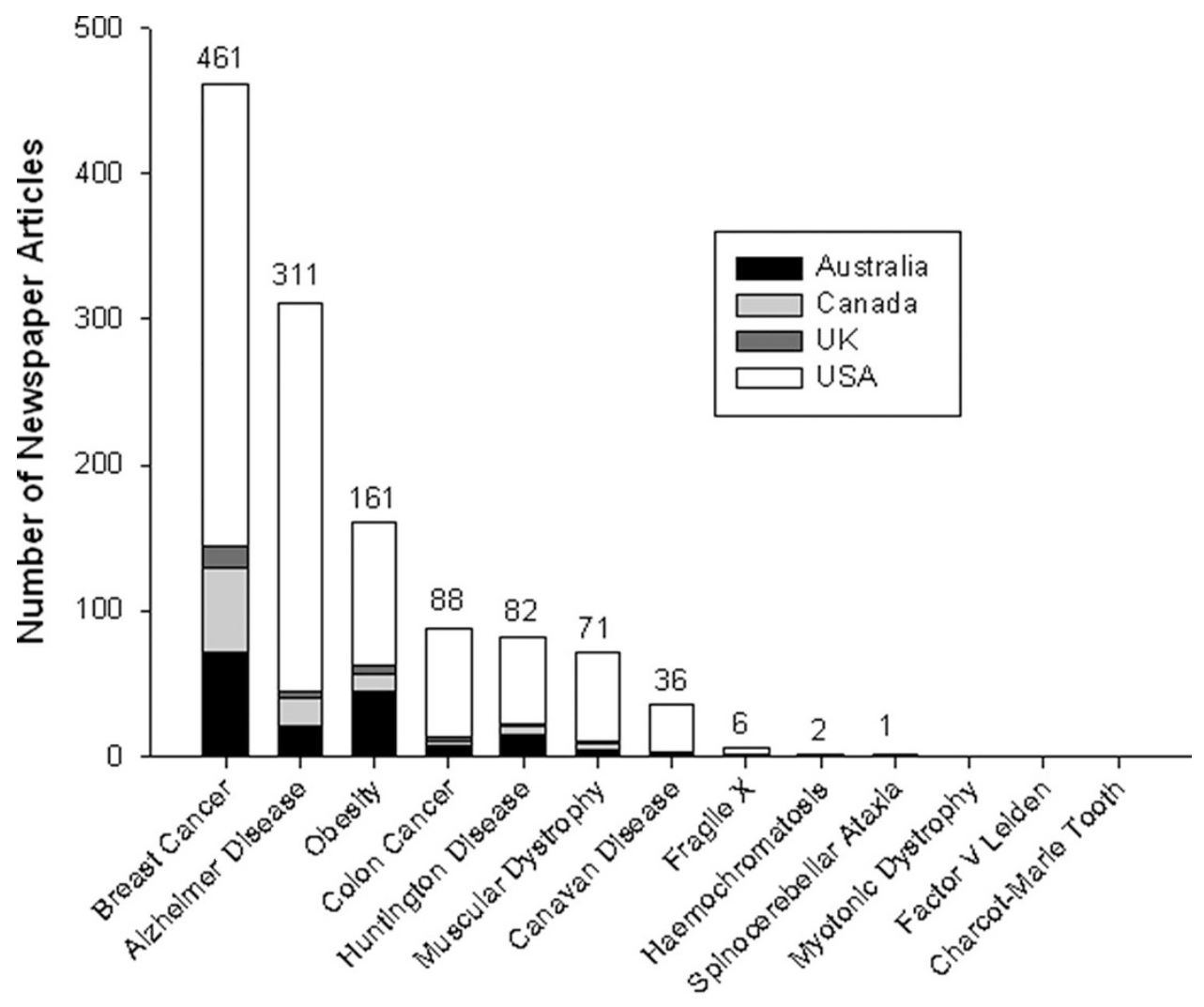

Disease

Fig. 1. Newspaper coverage of breast cancer BRCA1/2 patents compared with other potential disease gene stories.

$B R C A 2$ patent to the public sector Cancer Research UK. These stories were not covered in Canada. Finally, Myriad's patents reemerged negatively in the UK and Canada with the publication of Dr. King's article in JAMA ${ }^{11}$ that Myriad's test missed a significant number of mutations. In the US, this story was mainly covered in Utah from the perspective of Myriad, which rebutted that claim.

We coded the 143 newspaper articles from four jurisdictions that specifically addressed the issues raised by the BRCA1/2 patents: Canada (57), US (43), Australia (15), and the UK (28). Newspapers included major publications such as the Globe and Mail, The National Post, Sydney Morning Herald, The Australian, The New York Times, The Wall Street Journal, The Guardian, and The Independent. Almost all the articles (97.2\%) framed Myriad Genetic's BRCA1/2 patents as a controversy. This is not surprising given our criteria for inclusion in the study; however, only $55.9 \%$ (80) of articles were balanced in their coverage of that controversy (that is, presented a variety of perspectives). The majority of articles $(77.6 \%)$ had a negative overall tenor, only $6.29 \%$ had a positive overall tenor, whereas $16.1 \%$ were neutral. There were significant differences in the overall tenor between jurisdictions with Canadian coverage being overwhelmingly negative in comparison with the other three jurisdictions (Fig. 2). There were no significant differences in tenor of coverage between the US, Australia, and the UK. The overall negativity of coverage was further highlighted by the number of positive versus negative statements. The majority of articles (97.9\%) made negative statements about the $B R C A$ patents whereas only $59.4 \%$ (85) made at least one positive statement about the BRCA patents, but even though most of the articles raised concerns about the $B R C A$ gene patents, only $26.6 \%$ made any mention of policy recommendations to address these concerns.

Although the tendency toward a negative spin held in all of the four jurisdictions studied, interesting variations existed. There were significant differences between jurisdictions in the number of positive statements $(\mathrm{H}(3)=16.954 ; P<0.001)$ but no significant jurisdictional differences in the number of negative statements (median $=4$ ). In Canada, where the reaction to the cease-and-desist letters was particularly pronounced, ${ }^{12}$ the coverage was almost entirely negative. The majority of Canadian articles (54\%) made no positive statements whereas the majority of articles in other jurisdictions (79.1\%) made at least one positive statement. Coverage in the US was the most positive with $72.1 \%$ of articles making up to four positive statements. The coverage in the US was skewed by the large amount of positive coverage Myriad generated in Utah newspapers where Myriad is located. These papers reported the same issues as other newspapers, such as the patent controversies at the European Patent Office, but did so from the perspective of 


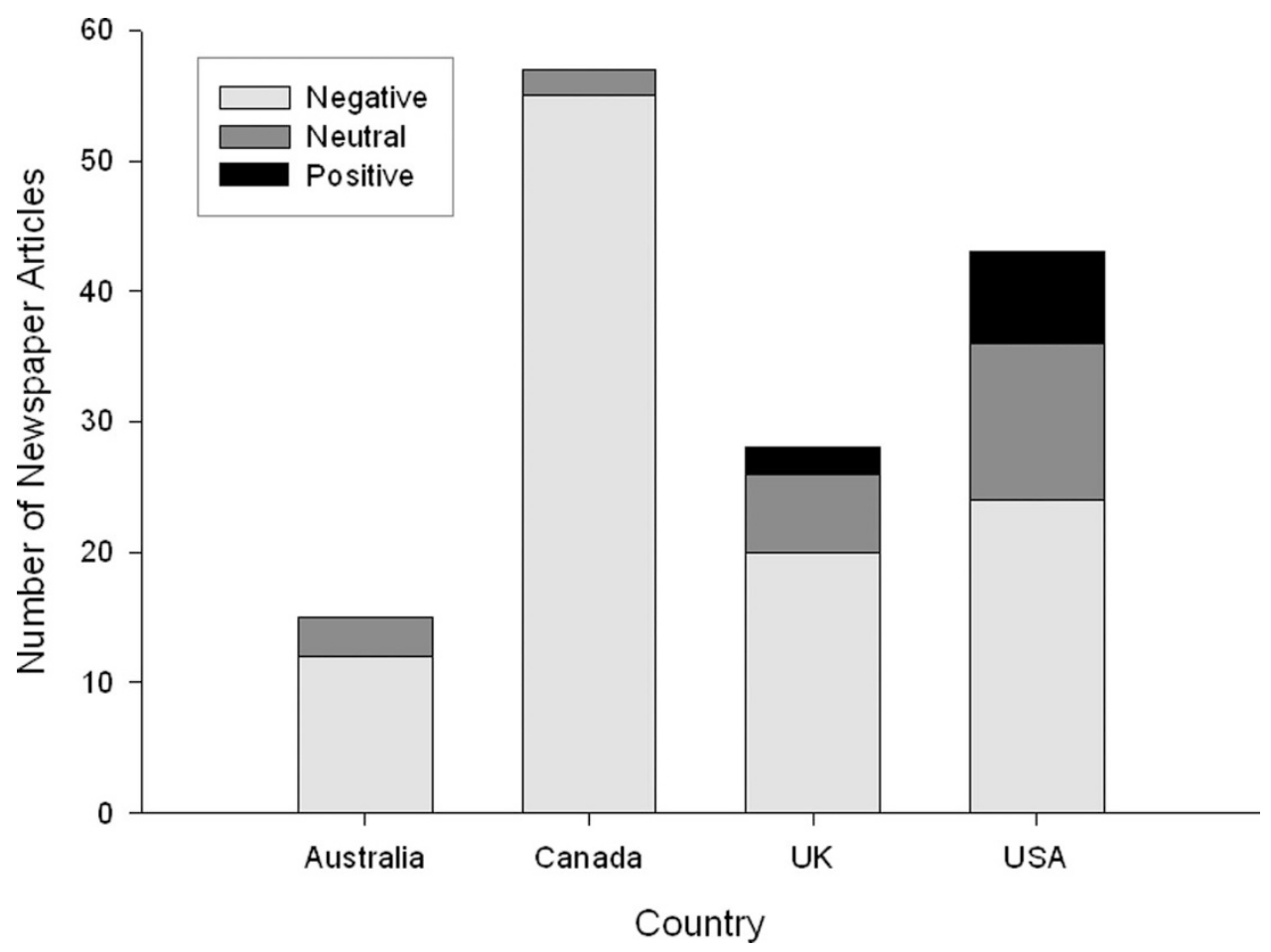

Fig. 2. Overall tenor of newspaper articles on Myriad Genetic's BRCA1/2 patents.

Myriad. This more muted response was also reflected in US policy, which was less reactionary in tone.

There was no significant difference between jurisdictions in the number of negative commentators cited with a median of one to two negative commentators being cited per article. Most negative sentiments were expressed by scientific researchers except in Canada where concerns were most commonly articulated by government officials. In Canada, the most common negative comments about the $B R C A$ gene patent were that the BRCA patents would "increase health care costs" (93.0\% of stories) and the claim that BRCA patents would "restrict access to health care" (also 93.0\%). These concerns were similarly articulated in the UK and Australia. Increasing health care costs was also the most common negative statement in the US, but it appeared in $65.1 \%$ of articles. In the majority of cases, these concerns, which arose specifically in the context of Myriad's patents, were generalized to all gene patents.

There was a significant difference in the number of positive commentators cited $(\mathrm{H}(3)=25.976 ; P<0.0001)$. Only $26 \%$ of Canadian articles cited a commentator in support of Myriad Genetic's patents, whereas the majority of articles in other jurisdictions cited at least one positive commentator. The most common positive statement was that patents would facilitate capital investment, a position that was usually put forward by a Myriad employee. However, again, there was some interesting jurisdictional variation. For example, this statement appeared in only $36.0 \%$ of the Canadian stories, but was noted in $58.1 \%$ of the US stories.

\section{DISCUSSION}

Not surprisingly, Myriad's patents were largely portrayed as a negative story and as an example of the problems associated with gene patents. The story was primarily framed as a social dilemma that needed to be addressed. The majority of stories in all jurisdictions occurred before the policy documents and followed the major social and ethical controversies related to gene patenting that played out most clearly at the European Patent Office (Fig. 3). In Canada, where there was a disproportionate level of coverage, the story largely covered the strong, and arguably also disproportionate, political response to the threat of patent infringement action against government testing laboratories. In this context, our data provide some support (albeit not direct evidence) that the media coverage helped to drive the policy agenda. Indeed, given the role that media plays as a source of biotechnology information, it is reasonable to speculate that these stories helped to legitimize the debate. ${ }^{5,7}$ And given the lack of balance in many of the stories, one could argue that the media coverage was a less than ideal source of information on the controversy. Moreover, the tone of the coverage and of the commentators referenced in the stories exemplify how, as noted by Kitzinger and Williams, " $[t]$ he media are a crucial site through which public issues are framed, serving as the focus of intense lobbying and acting as an arena within which policy struggles are defined and played out." 13

It is also interesting to note that the many policy reports and suggested reforms received very little media attention. In some ways, the lack of coverage is not surprising. The media tends to 


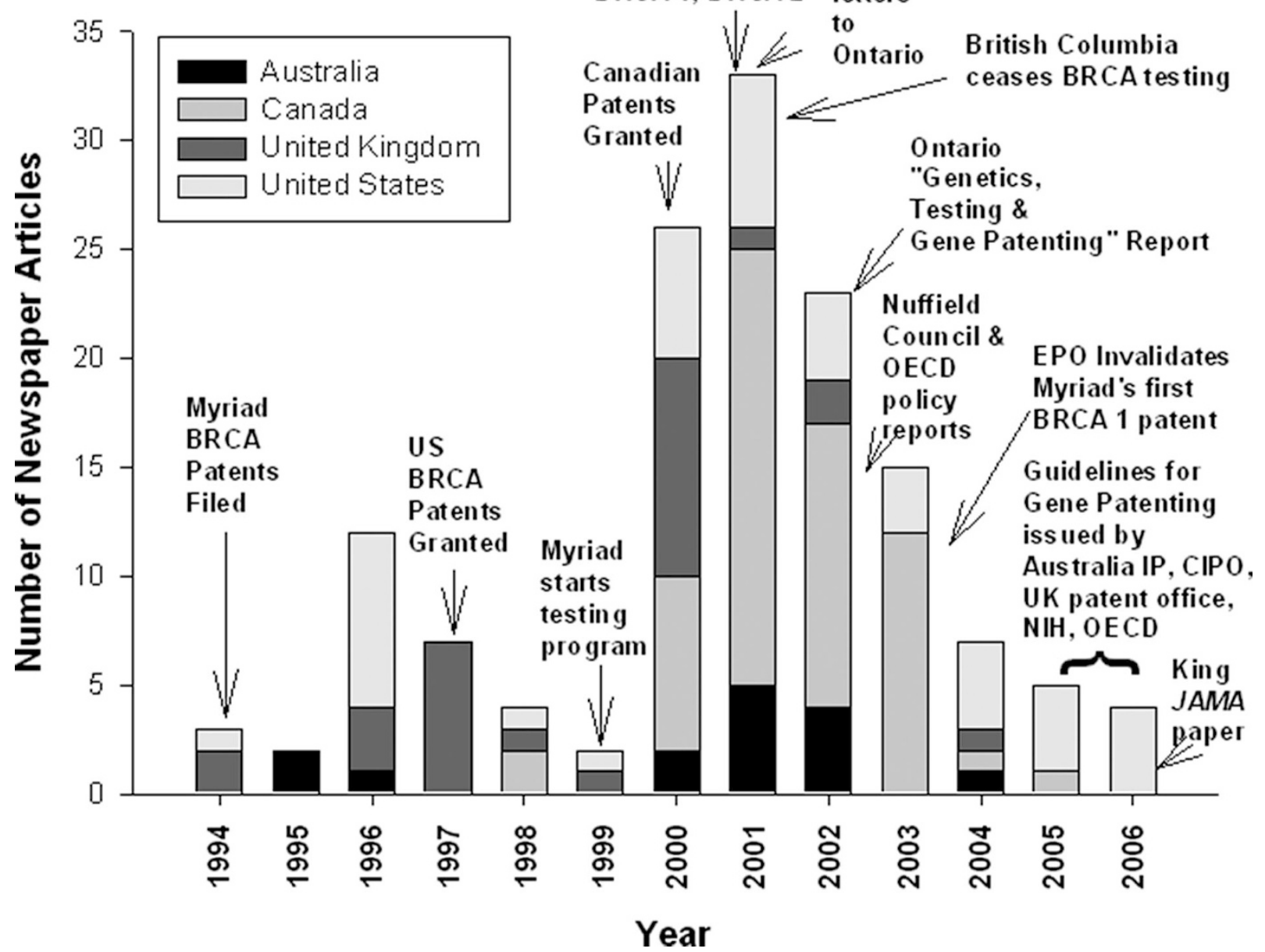

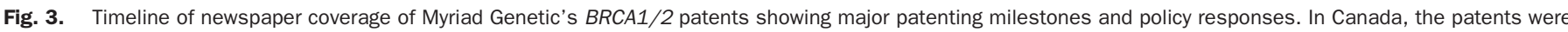

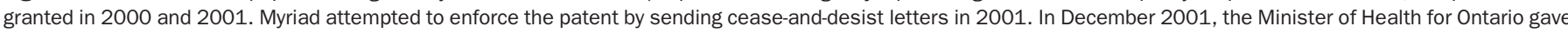

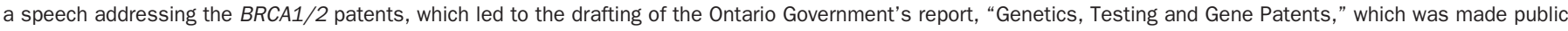
at the end of January 2002.

frame health and science stories as either "miracle breakthroughs" or social controversies. ${ }^{14}$ This type of polarized reporting is seen in other areas, such as in the area of stem cell research. ${ }^{15}$ Reforms to the patent system, no matter how radi$\mathrm{cal}$, may not be viewed as particularly newsworthy. The main triggers for news coverage were local concerns, such as licensing deals, controversies, and actions at regional patent offices, particularly in Europe, publications in the major scientific journals, including the survey by Cho et al. ${ }^{10}$ that showed that most genetic testing facilities had ceased testing for some conditions because of the threat of patent infringement, and statements by public figures, for example President Clinton, Prime Minister Blair, and the activist, Jeremy Rifkin.

This trend was most noticeable in Canada where the majority of the coverage was generated by statements made by Ontario's Conservative Premier, Mike Harris and Health Minister, Tony Clement. These politicians cast Myriad as villain, threatening the fabric of Canada's publicly funded health care system. At this time, health care reform was a key national concern. For example, a major national commission on the future of Canada's health care system occurred between 2000 and $2002 .{ }^{16}$ The idea that gene patents would have an adverse impact on the health care system fit well with existing health policy discussions. Indeed, the view that patents would drive up health care costs and reduce access were the most commonly articulated concerns in the Canadian press, and most articles had nothing positive to say about patents. At the annual Premier's conference in 2001 Premier Harris called upon all Provinces to "defy" Myriad and coverage of the Provinces positions on compliance continued through 2003. British Columbia, which had originally ceased $B R C A$ testing, reconsidered, whereas Alberta announced it would not comply with the ceaseand-desist order. However, the threatened litigation never came about and by the end of 2003, other health stories dominated the Canadian media. 
Finally, it is worth considering the possible impact of the media coverage on the general public's perceptions. ${ }^{17}$ There is evidence that the media can impact public attitudes in the realm of biotechnology. ${ }^{18,19}$ Did the media coverage of the Myriad event help to shift perceptions of gene patents? A study from Canada, the jurisdiction with the most clearly negative media reports, shows that the public became less favorable toward biotechnology patents around the time of the Myriad controversy. A 2002 survey of Canadians on biotechnology patents found that " $46 \%$ said there are likely more risks than benefits in allowing such patents, up from 37\% in 2000." 20 Of course, one needs to be careful not to assume a linear transmission of information and opinions from the media to the public and policy makers. The relationship is obviously complex. ${ }^{8}$ Media portrayals of biotechnology both reflect and inform public perceptions. Nevertheless, it is certainly possible that media representations played a role in shaping the public views in this context, particularly in Canada where the political rhetoric was strongest and the media coverage most negative.

\section{ACKNOWLEDGMENTS}

We thank Genome Alberta for the funding support and Edna Einsiedel and Mike Sharp for their assistance.

\section{References}

1. Caulfield T, Cook-Deegan B, Kieff S, Walsh J. Evidence and anecdotes: an analysis of human gene patenting controversies. Nat Biotechnol 2006;24:1091-1094.

2. Matthijs G. The European opposition against the BRCA gene patents. Fam Cancer 2006;5:95-102.
3. Eggertson L. Ontario defies US firm's genetic patent, continues cancer screening. CMAJ 2002;166:494.

4. Williams-Jones B. History of a gene patent: tracing the development and application of commercial BRCA testing. Health Law J 2002;10:123-146.

5. Ten Eyck T, Williment M. The national media and things genetic. Sci Commun 2003;25:129-152.

6. Marks L, Kalaitzandonakes N, Wilkins L, Zakharova L. Mass media framing of biotechnology news. Public Underst Sci 2007;16:183-203.

7. Nisbet M, Lewenstein B. Biotechnology and the American media: the policy process and the Elite Press, 1970 to 1999. Sci Commun 2002;23:359-391.

8. Bauer M. Public perceptions and mass media in the biotechnology controversy. Int J Public Opin Res 2005;17:5-22.

9. Field A. Discovering statistics using SPSS, 2nd ed. London: Sage Publications, 2005.

10. Cho MK, Illangasekare S, Weaver MA, Leonard DGB, et al. Effects of patents and licenses on the provision of clinical genetic testing services. J Mol Diagn 2003;5:3-8.

11. Walsh T, Casadei S, Coats KH, Swisher E, et al. Spectrum of mutations in BRCA1, BRCA2, CHEK2, and TP53 in families at high risk of breast cancer. JAMA 2006;295: 1379-1388.

12. Caulfield T. Policy conflicts: gene patents and health care in Canada. Community Genet 2005;8:223-227.

13. Kitzinger J, Williams $\mathrm{C}$. Forecasting science futures: legitimizing hope and calming fears in the embryo stem cell debate. Soc Sci Med 2005;61:731-740.

14. Highfield R. Selling science to the public. Science 2000;289:59.

15. Nesbit M, Mooney C. Framing science. Science 2007;316:56.

16. Romanow. Building on values: the future of health care in Canada-final report. Saskatoon: Commission on the Future of Health Care in Canada, 2002.

17. Caulfield T, Einsiedel E, Merz J, Nicol D. Trust, patents, and public perceptions: the governance of controversial biotechnology research. Nat Biotechnol 2006;24:13521354.

18. Laing A. A report on news media effects and public opinion formation regarding biotechnology issues: a study commissioned by the Canadian Biotechnology Secretariat. Ottawa: Cormex Research, 2004.

19. Nisbet M. The polls—-trends: public opinion about stem cell research and human cloning. Public Opin Q 2004;68:131.

20. Government of Canada, Seventh Wave. Public opinion research into biotechnology issues: report prepared for and presented to the Biotechnology Assistant Deputy Minister Coordinating Committee (BACC), Government of Canada. Ottawa: Pollara and Earnscliffe Research and Communications, 2002. Available at: http://www. biostrategy.gc.ca/english/view.asp? $\mathrm{x}=547 \&$ \&all $=$ true Accessed July 14, 2007. 